\title{
空圧駆動超冗長アクチュエータによるマニピュレーション*
}

伊達 央 $^{* 1}$, 滝田 好宏 ${ }^{* 1}$

\section{Manipulation of a Pneumatic Hyper-Redundant Actuator}

\author{
Hisashi DATE ${ }^{* 1}$ and Yoshihiro TAKITA \\ ${ }^{* 1}$ Department of Computer Science, National Defense Academy \\ 1-10-20, Hashirimizu, Yokosuka, Kanagawa, 239-8686, Japan
}

Pneumatically controlled and actuated planar snake-like device has been developed. Each joint is controlled by hardware-implemented algorithm inspired by snake's lateral undulatory locomotion. Therefore the device progresses forward whenever the lateral movement is constrained, such as a winding groove by which the tip element is guided. Without lateral constraint, the device behaves like a elephant trunk. This paper focuses on the behavior as an manipulator. Endoscopic manipulation through a complicated cavity is demonstrated by experiments.

Key Words : Manipulator, Robot, Actuator, Pneumatic Equipment, Distributed Control, Snake-Like Locomotion

\section{1. は じめ に}

蛇は細長い体形と脚を用いずに体の屈曲のみによって推進する独特の移動方法により，狭隘空間や不整地におい て優れた運動能力を有している. 蛇行推進の本質は, 横方向への運動が前後方向の運動に比べて制限される点に ある. 体幹の屈曲力が横方向の抵抗力を生み, 乥れが推進力に変換される. 弚の能力を工学的に再現すべく, こ れまでに蛇型ロボットの研究が盛んに行われている.蛇型ロボットは, 多数の剛体リンクが回転関節を通じて結 合された多リンク系として実現されることが多いが，高のまま多リンク系と捉えてモデル化すると，一般に自由 度と共に複雑さが増加するため, 生体のように 100 を超える多数の関節を持つ滑らかな運動の扱いが困難となる. これに対して，体幹を連続な曲線として扱い，曲線の幾何学量である曲率を用いて解析する方法がある．

蛇型ロボットの先駆的研究を行ってきた広瀬らは，はじめに体幹を多リンク系として捉え，リンク長を0にす る極限を取って連続な曲線として表し, 静止状態における横方向の拘束力と屈曲力の釣り合いの式を元にして屈 曲力と拘束力の関係を導いた ${ }^{(1)}$. また, 筋力の周期的な運動は正弦波に従って变化するのが自然であるとの解釈の もと, 曲率が正弦波状に変化する曲線を見出し, サーペノイド曲線と名付けた . 連続体による屈曲力と拘束力の 関係式を用いて，サーペノイド曲線をクロソイド曲線等の他の曲線と比較したり，サーペノイド曲線の最適なパ ラメータを導出している．しかしながら，屈曲力分布については指数分布に従うという仮定がなされており，考 察の余地を残している.Chirikjian らは超冗長マニピュレータの運動学モデル ${ }^{(2)}$ 及び動力学モデル ${ }^{(3)}$ を提案してい る.汎用的な表現が示されているが, 環境からの作用は外力として扱われているため, 蛇行推進の本質である横 方向への拘束がある場合の運動を明示的に示すことは困難である.

蛇行推進の性質を突き詰めていくと, 横方向の運動が完全に拘束され, 前後方向には摩擦無く滑り, 体幹の至る 点で曲げ力を発生する事ができる連続な曲線の運動に帰着させることができる．光こで筆者らは拘束か陽に考慮 された蛇行運動に対する連続体モデルを導出した . これにより，与えられた体形に対して屈曲力の二乗和が最小 となるような最適な屈曲力分布を求める問題が幾何学的に定式化できるようになり, 弚の解は曲率の弧長に関す る微分に比例する分布であることが明らかとなった ${ }^{(4)}$. 曲率の微分は局所的な幾何学量であるため, 屈曲力の計算

\footnotetext{
* 原稿受付 2010 年 11 月 12 日

${ }^{*}$ 正員, 防衛大学校情報工学科（盯239-8686 神奈川県横須賀市走水 1-10-20）

E-mail: date@nda.ac.jp
} 
は各点近傍で完結させることができるのに対して , 全体として最適な力分布が得られる点が特徵的である.生体

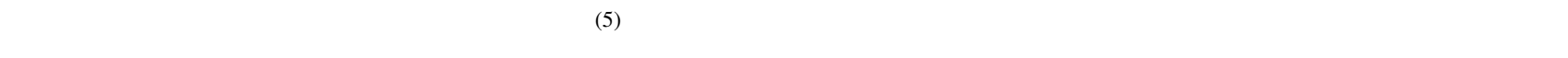
山田らは, この曲率微分に基づく最適屈曲力分布を用いて, 蛇が平地を移動する際に体幹の一部を浮かせ , 荷重 を特定の点に集中させる Sinus-lifting の運動の解析に用いている ${ }^{(6)}$.

最適屈曲力分布の局所性は，実際の蛇型ロボットで多く見られる，有限個のリンクが連結された形態において も近似的に成り立ち，弚れは 1 つ前の関節角を目標角とする比例制御系によって実現することができる .この制 御則はまず横滑りを防ぐ受動車輪を備えた DC モータによって駆動された蛇型ロボットに適用し，先端の軌道を 適切に制御することで平面上を持続的に推進することを実証した ${ }^{(4)}$.この単純な制御則は，電子回路を用いること なく，純粋な機械構造のみによって実装することも可能であり，光の具体例として流体サーボを応用した蛇型推進 機構を開発した ${ }^{(7)}$.この機構は, 先端が屈曲すると光の角度が後続の関節に伝播する性質を持っており，蛇行した 溝の中で横方向の動きを拘束した状態では, 加圧空気を供給するだけで推進するものである . 空気圧を駆動力と して用いる蛇型ロボットはこれまでにも開発されているが( ${ }^{(8)}$, いずれも制御には電磁バルブや電子回路等を用いて おり，本機構は制御兴のものを流体の作用で完結している点で大きな違いがある .

本稿では，この推進機構を応用し，マニピュレータとして活用する問題を考察する.マニピュレータとして用 いる場合，必ずしも体幹のすべての点において横方向の運動が拘束されるわけではないため，弚のような場合の 挙動についての考察が必要となる.1つ前の関節と同じ角度に収束させる制御則は, 拘束がなければ最終的に先端 の曲率と同一の曲率をもつ円弧形状が安定であるという性質を持つ.したがって，先端部分の屈曲角を人為的に 操作できる仕組みを用意しておけば, 先端のみを操ることで体幹の形状か変化する象の鼻のような超冗長マニピュ レータとしての機能を付与することができる．弚こで, 狭隘空間における推進と先端部のマニピュレーションを 組み合わせた問題を考え，実験により有効性を検証する．

本論文の構成は以下の通りである. 第 2 節において連続体モデルの基礎式の概略を述べる . 続いて第 3 節におい て, 流体サーボを応用した推進機構の概要を述べる . 第 4 節では, 先端が拘束されない場合の挙動について, 理 論的考察と実験による検証結果を述べる．第 5 節でマニピュレータとしての検証実験について述べる .

\section{2. 連 続 体モ デル}

\section{$2 \cdot 1$ モデルの設定と導出}

本節では，本研究の基盤となっている連続体モデルの概略を述べる . 理論式展開の 3 次元まで拡張され，詳細 は既報 ${ }^{(4)}(7)$ に示されているが，ここでは 2 次元平面の運動について述べる. 図 1 に示すように，体幹を全長 $L$ の 弧長 $s \in[0, L]$ で計数付けられた連続な曲線として表現し，次の仮定を置く．

1. 体幹は伸縮しない

2. 体幹の接線に垂直な方向の速度は 0

3. 体幹の接線方向には摩擦無く滑るか一樣な動摩擦力を受ける

4. 任意の点で屈曲力が発生できる

仮定 1 と 2 より，体幹の至る点が先端の通過した軌跡を通過し，接線方向の速度 $v$ と加速度 $\alpha$ は一樣であること が導かれる . 接線方向の摩擦については，任意の摩擦力をモデルに組み込むことは可能ではあるが，解析のしや すさから，摩擦無しあるいは一樣な動摩擦であるという仮定を置いている．

この仮定のもとでは, 系の運動は先端の曲率と接線方向の運動に集約され, 先端の曲率と体幹の屈曲力分布が

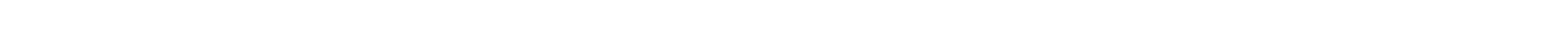

$$
\begin{aligned}
& f_{t}^{\prime}(s)=\rho \alpha+q(s) \kappa(s)+F_{r} \\
& q^{\prime}(s)=-f_{n}(s)-f_{t}(s) \kappa(s) \\
& \tau^{\prime}(s)=-q(s)
\end{aligned}
$$

ここで, $f_{t}(s)$ は接線方向の圧縮力,$\rho$ は線密度,$q(s)$ はせん断力,$\kappa(s)$ は曲率,$F_{r}$ は単位長さあたりの接線方向の 摩擦力, $f_{n}(s)$ は法線方向の拘束力, $\tau(s)$ は曲げモーメントで, 記号' は弧長に関する微分を表す.式 (3) を式 (1) に 
代入して $q$ を消去しての両辺を 0 から $L$ まで積分し，端点で圧縮力が作用しないという境界条件 $f_{t}(0)=f_{t}(L)=0$ を用いると

$$
\left[f_{t}(s)\right]_{0}^{L}=\int_{0}^{L}\left(\rho \alpha-\tau^{\prime}(s) \kappa(s)+F_{r}\right) d s=0
$$

が得られ，さらに部分積分 $\int_{0}^{L} \tau^{\prime} \kappa d s=[\tau \kappa]_{0}^{L}-\int_{0}^{L} \kappa^{\prime} \tau d s$ と端点で曲げモーメントが作用しないという境界条件 $\tau(0)=\tau(L)=0$ を用いて，接線方向の運動方程式を得る．

$$
m \alpha=-\int_{0}^{L} \tau(s) \kappa^{\prime}(s) d s-F_{r} L
$$

ここで, $m:=\rho L$ は全質量である.

$2 \cdot 2$ 最適化問題と離散近似

与えられた接線方向加速度 $\alpha$ に対して , 曲げモーメントの二乗和に相当する評価関数

$$
J=\int_{0}^{L} \tau^{2}(s) d s
$$

を最小にする曲げモーメント分布 $\tau(s)$ を求める問題は, 一般的な等周問題として定式化でき，乥の解 $\tau^{*}(s)$ は

$$
\tau^{*}(s)=-\frac{m \alpha}{\int_{0}^{L} \kappa^{\prime 2}(s) d s} \kappa^{\prime}(s)
$$

によって与えられる . 簡略な証明は, 方程式 (5) を 2 関数 $\tau, \kappa^{\prime}$ の内積とみなし， $\tau$ のノルムに相当する評価関数 (6) を最小化する関数 $\tau$ は, 関数 $\kappa^{\prime}$ の定数倍でなければならないという理屈から導くことができる.最適解 (7)に おいて, 分数で表される部分は $s$ にいて定数であり, よって分布形状は $\kappa^{\prime}(s)$ に比例したものとなる.

有限個のリンクによって構成されるモデルにおいては, 曲率は関節角 $\phi_{i}$ と対応関係にある . 同樣に曲率の弧長 に関する微分は隣接関節の角度差に, 曲げモーメントは関節卜ルクに対応する．よって, 連続体モデルの最適化 (7) は次のように離散近似できる .

$$
\tau_{i}=K\left(\phi_{i-1}-\phi_{i}\right)
$$

ここで $K$ は

$$
K=\frac{L m \alpha}{n \sum_{i=2}^{n}\left(\phi_{i-1}-\phi_{i}\right)^{2}}
$$

で与えられる $\tau_{i}$ および $\phi_{i}$ は弚れ光れ $i$ 番目の関節トルク，関節角であり， $n$ はリンク数である.

近似式 (8) は，先行関節角 $\phi_{i-1}$ を目標角とし，比例ゲイン $K$ であるような $\mathrm{P}$ 制御系とみなすことができる.$K$ を定数とした場合，実現される加速度は近似的に

$$
\alpha=\frac{K n}{L m} \sum_{i=2}^{n}\left(\phi_{i-1}-\phi_{i}\right)^{2}-\frac{F_{r} L}{m}
$$

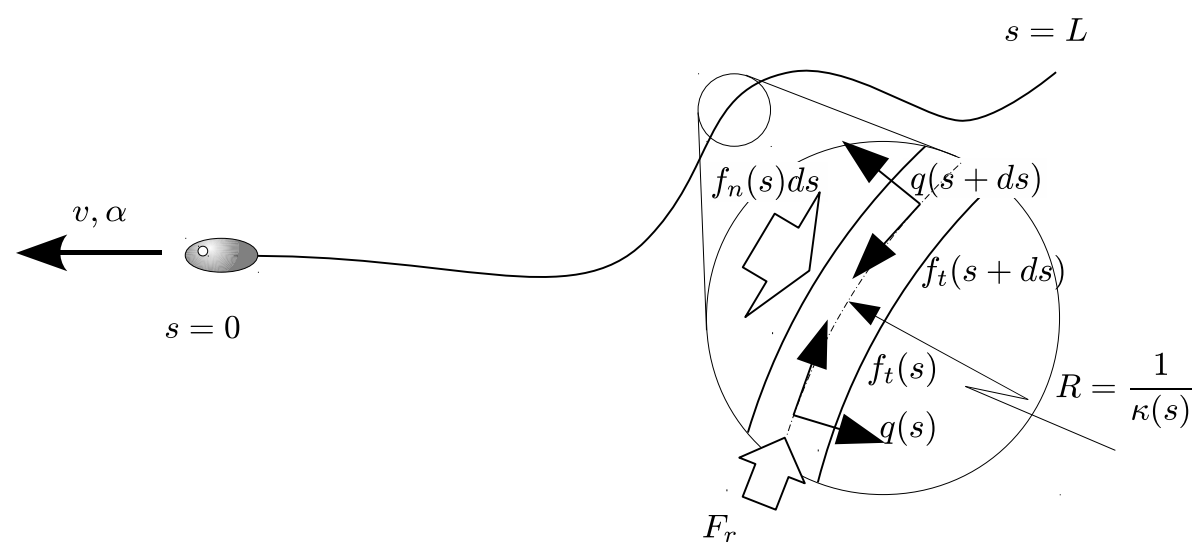

Fig. 1 Continuous curve parametrized by arc length $s$ expressing backbone curve of a snake 
で与えられる . 加速度は体形によって決まる $\sum_{i=2}^{n}\left(\phi_{i-1}-\phi_{i}\right)^{2}$ に左右され，特に円弧や直線状においては值が 0 と なるが，これは特異姿勢の説明を与えている．

連続体モデルによってこれまでに導かれた結論は，先行関節角を目標値とする比例制御系によって，全体を最 適化する近似解 (8) が得られるという点である.この制御系は単純さゆえ，樣々な方法により実装可能である．マ イクロコントローラやアナログ演算素子等電子回路を用いることで容易に構成できる他 , 次節で述べる流体サー ボのように，純粋な機構のみで実現することも可能である .

\section{3. 流体サーボを応用した推進機構}

\section{$3 \cdot 1$ 基本原理}

連続体モデルに基づく近似最適化屈曲力分布は, 先行関節と現関節との角度差に比例したトルクを発生できれ ば実現できる . 自動車の油圧式パワーステアリングに見られるような流体サーボは , 入力軸と出力軸の角度差に 応じて油圧系の流路か湾化し，最終的に差が 0 となるように油圧アクチュエータで出力軸を駆動するものである これを蛇行推進に応用するには，隣接する 2 関節の角度差を機械的に同軸に実現すればよい . 図 2 は, 後続の関 節軸上に先行関節との角度差を生成する歯車・リンク機構を示している．最小の機能は 2 関節 3 リンクにより構 成されるが, 同一の構造を 1 リンクずつ追加することにより，任意個数に拡張することができる．リンク 1 は歯 車 A と岡に結合され，歯車 B は関節 2 を回転軸として自由に回転し，歯車 A と噛み合っている (図 2 (a)) . リン ク 1 を時計回りに旋回させると，関節 1 において, リンク 2 との間に相対角 $\phi$ が発生する (図 $2(b))$. この際, 関 節 2 の関節角，すなわちリンク 2 とリンク 3 のなす角は 0 である . 歯車の伝達により，関節 1 と関節 2 の角度差 が, リンク 3 と歯車 B の同一軸上の角度として現れている . この差を 0 にするように，関節 2 においてリンク 2 とリンク 3 の間にトルクを作用させれば，最終的に図 2 (c) のように同一の関節角を持った状態に収束する . この 制御を実現するには，流体サーボ系の入力軸を歯車 B に，出力軸をリンク 3 に接続すればよい．

図 3 は流体サーボ機構と組み合わせた動作を示したものである . 先行関節であるリンク 1 が時計回りに旋回す ると，歯車 B に結合されたバルブが反時計回りに回転し，左側の気室へ高圧空気が流入する．すると左側のピス トンが押し出され，リンク 3 を反時計回りに旋回させるトルクが発生する . 右側の気室の空気は, 排気口を通じ て大気開放される .リンク $1-2$ の相対角とリンク $2-3$ の相対角が等しくなった時点で流路が閉じられる . 以上

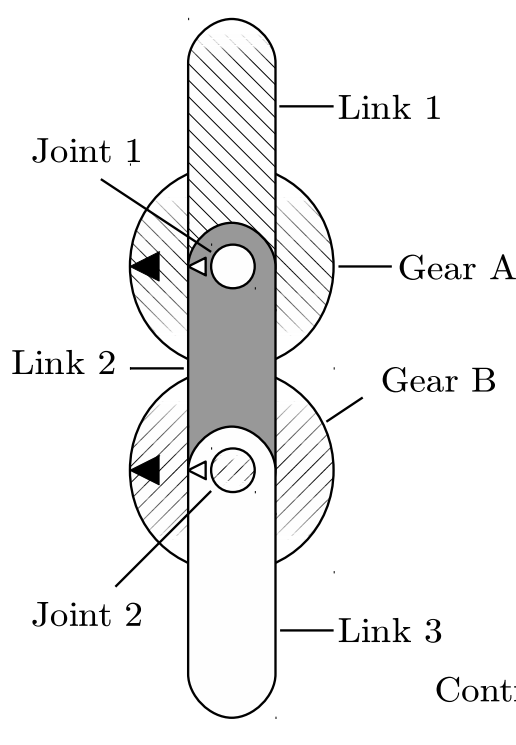

(a)

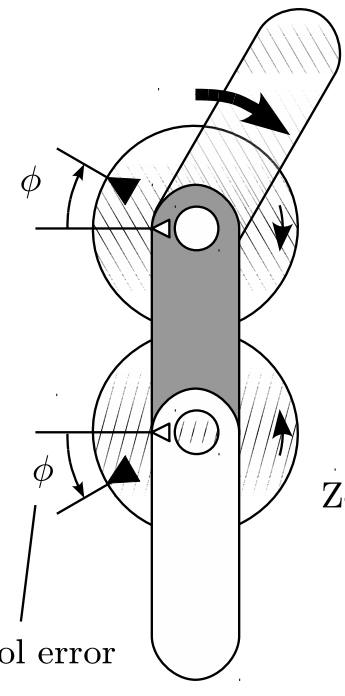

(b)

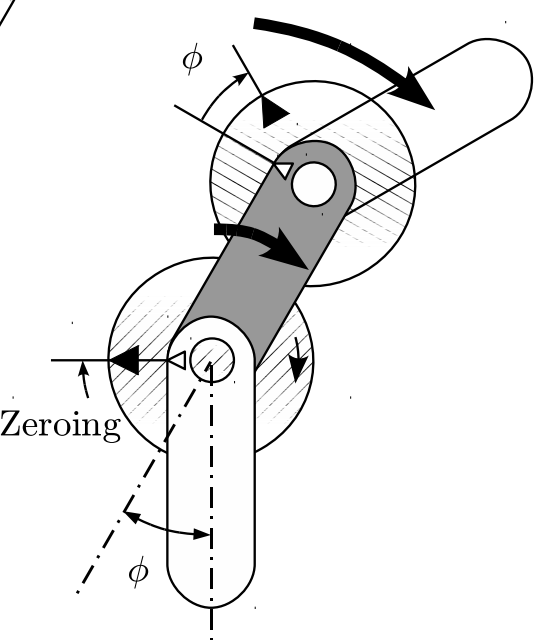

(c)

Fig. 2 Schematic model of link and gear system that generate joint angle difference on the posterior joint: (a) Straight shape (b) Link 1 turned clockwise by $\phi$, Gear B turned counter clockwise by the same amount (c) Link 1 and 2 turned cloclwise by zeroing the control error 


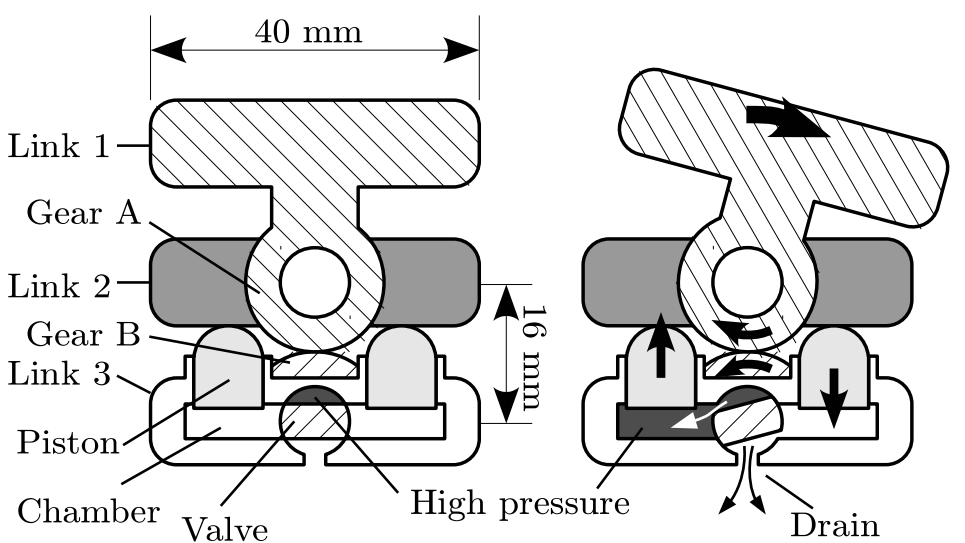

(a)

(b)

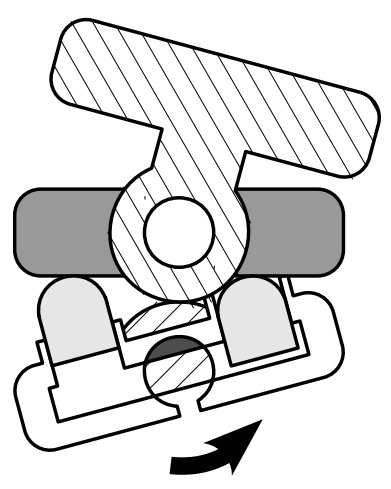

(c)

Fig. 3 Fluid servomechanism combined with link and gear system: (a) Straight shape (b) Link-1 turned and second joint driven by fluid servo (c) Destination shape

Table 1 Specifications of the prorotype

\begin{tabular}{|c|c||c|c|}
\hline Link width & $40 \mathrm{~mm}$ & Maximum joint angle & $13 \mathrm{deg}$ \\
Joint interval & $16 \mathrm{~mm}$ & Maximum torque & $0.42 \mathrm{Nm} / \mathrm{MPa}$ \\
Minimum inner radius & $50 \mathrm{~mm}$ & Weight & $31.5 \mathrm{~g}$ \\
\hline
\end{tabular}

により，先行関節の関節角に追従するように後続関節か駆動される流体サーボ系が構成される．

\section{$3 \cdot 2$ 試作機}

図 4-6 に示すような試作機を製作した . 主な諸元を表 1 に示す. 本体はジュラルミン , バルブは黄銅 , 歯車 B

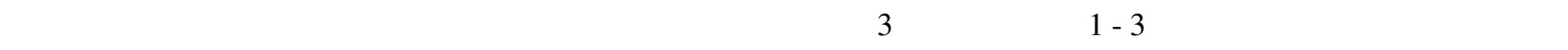
実際には図 4 に示すように，同一の構造の繰り返しとなっている . 干渉回避のため，歯車 A , B はいずれも一部 のみ創成されている . 歯車 A と一体に加工されたカバーには, 配管チューブの接続口が設けられており，片方の 接続口から導入された高圧空気は図 3 (a) におけるリンク内部の高圧気室に通じているとともに , もう一方の接続 口にも通じている．前後リンクの接続口を数珠嗦ぎに配管し，最も先端に位置する駆動関節のある第 3 リンクの 接続口を塞ぐことにより, 最後尾のリンクから供給した高圧空気を全リンクに行き渡らせることができる . 配管 には柔軟なシリコーンチューブを用い, 関節の動きを阻害しないよう，十分な長さを持たせてある .このため, 本 試作機においては高さ方向に余裕がある空間でなければ推進することができないが, 各関節を中心として屈曲可 能な配管を用いることにより，高さ方向においても小型化することが可能である . 先端部は , 図 5 に示すように， ワイヤによって屈曲角が操作できるようになっている .これにより操作者の意図に従って先端部の屈曲角が定ま り, 後続の関節か蛇行推進原理に従って屈曲する。

\section{$3 \cdot 3$ 基本特性}

最適屈曲力 (7) は, バルブとリンクの相対角に比例したトルクが発生し , かつ比例ゲインが全ての関節において 一樣であることを要請するが, 流体サーボにおけるゲインは弁や間隙の形状等や流体の特性に左右され，一般に は非線形であると考えられる . 乥こでサーボがどの程度の線形性を有するかを確かめるために，バルブを固定し， リンク対して作用させるトルクを変化させた時の角度偏差を測定した . 図 7 は, 樣々な供給圧力における, 角度 偏差と発生トルクの関係を示したもので, $0.5 \mathrm{MPa}$ の時の最小二乗回帰直線を重ねて表示している.角度偏差が大 きくなると発生トルクが飽和する傾向がみられるが，偏差が小さい領域では線形性がみられる . 線形領域のサー

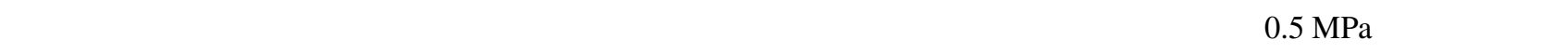
定実験の範囲内で良好な線形性が確認された . この時の比例ゲインは $39.5 \mathrm{mNm} / \mathrm{deg}$ であった . 


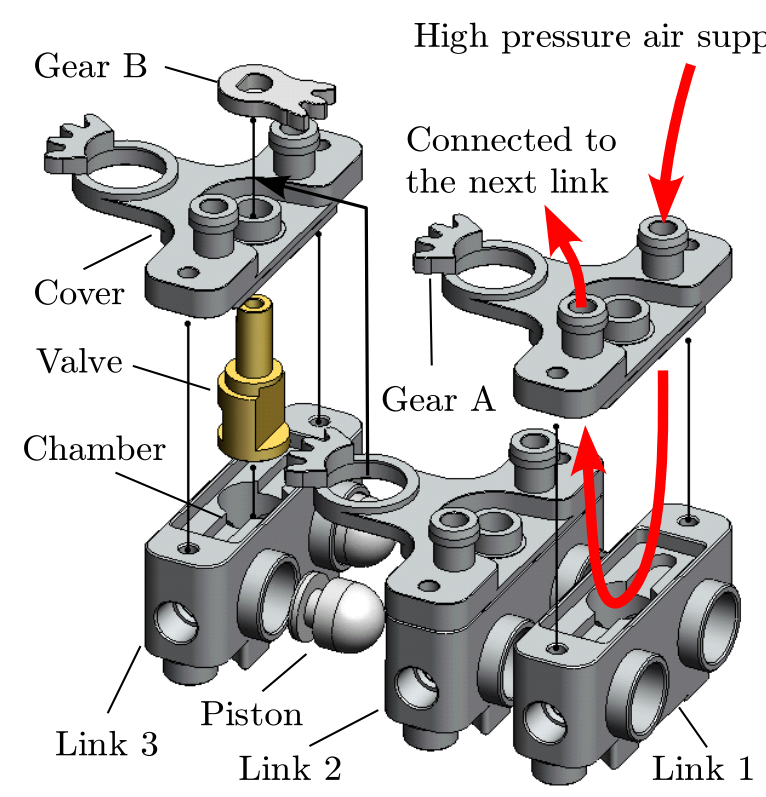

Fig. 4 Disassembled components of the prototype

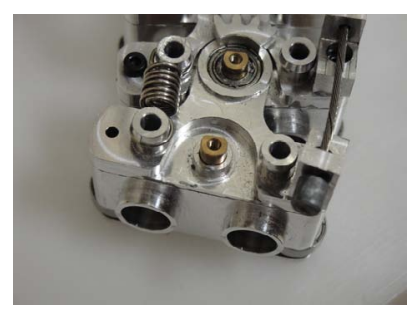

Fig. 5 Head link attached with Bowden cable

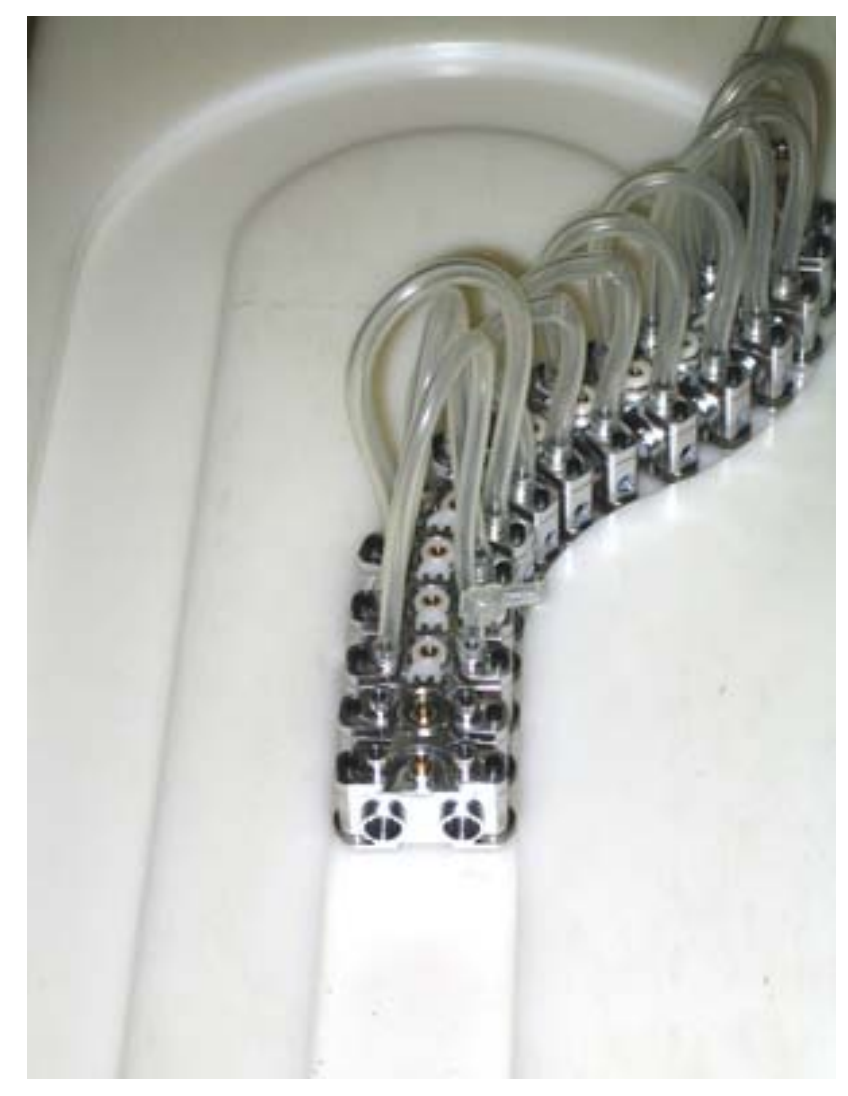

Fig. 6 Front view of the assembled prototype

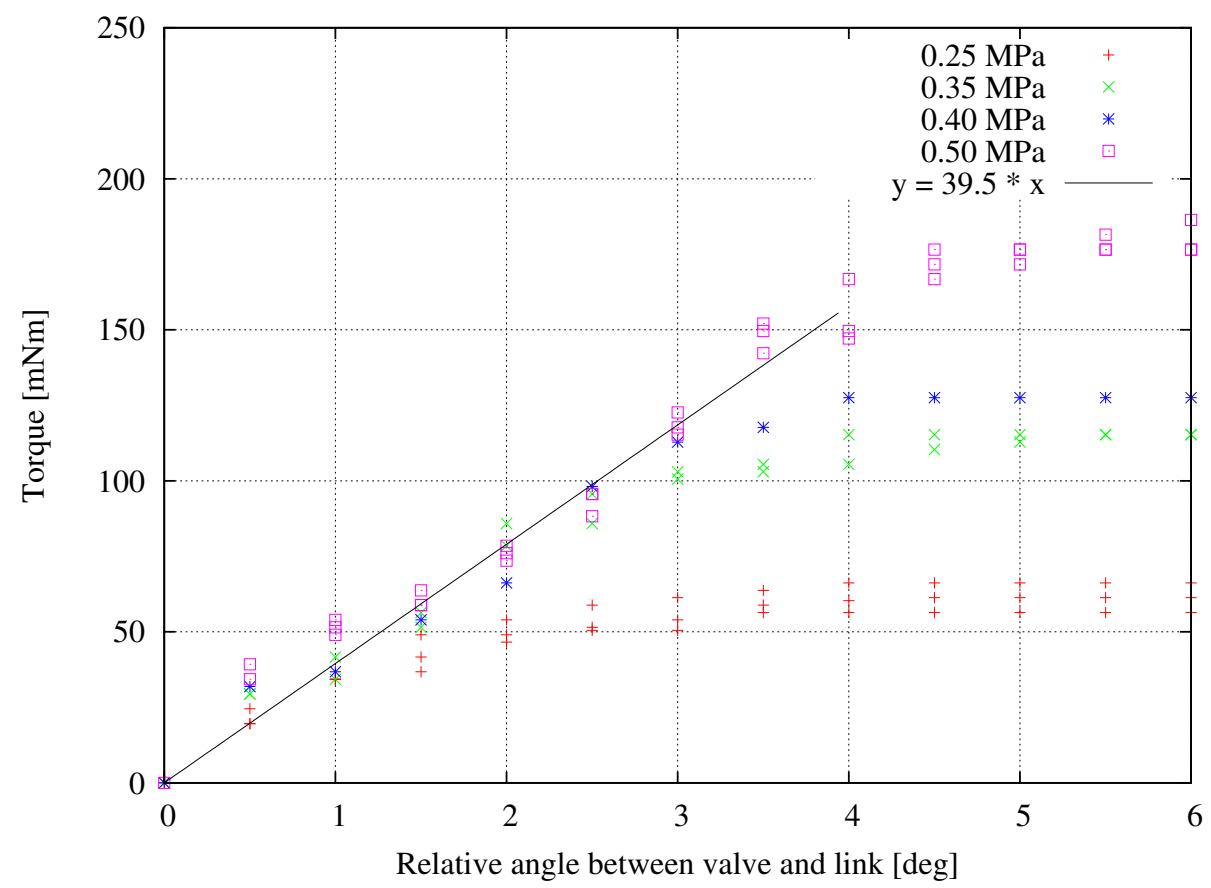

Fig. 7 Torque versus relative angle between link and valve as control error

\section{4. 先端が拘束されない場合の挙動}

2 章で導出した連続体モデルは，体幹が左右方向に拘束されることを仮定しており，拘束されていない場合の挙 動を記述しない .マニピュレータとしての機能を考える場合 , 拘束されていない場合の挙動を把握しておくことは 


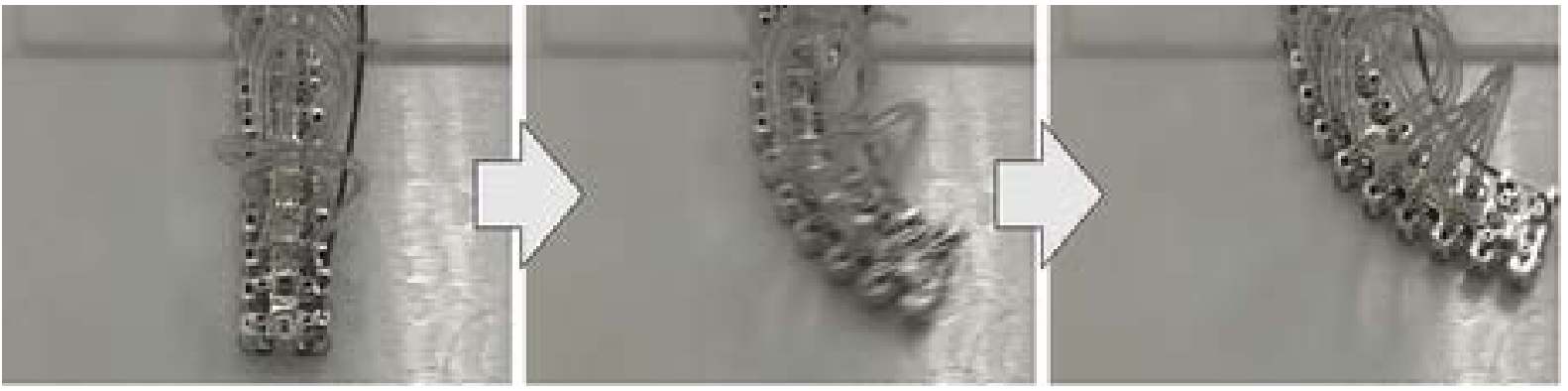

Fig. 8 Behavior of 9 unconstrained links

重要である . 先端部分が拘束されずに静止状態にある場合，外力が作用しないため，せん断力，曲げモーメント， 圧縮力等の内力はいずれも 0 となった状態て釣合う.連続体モデルにおける最適屈曲力制御 (7) を作用させた場合， 曲率の微分に比例する曲げモーメントが 0 となる.ゆえに， $\kappa^{\prime}(s) \equiv 0$ が成り立つ.これは一定曲率曲線，すなわ ち円弧であることを意味しており，先端の曲率 $\kappa(0)$ をワイヤにより操作すれば，拘束されない部分は半径 $1 / \kappa(0)$ の円弧の形状に安定する、離散近似した場合でも，制御則 (8) が先行関節角を目標角とする制御であることから， 各関節角が一樣となる形状が安定である . 実験的に円弧形状に収束することを確かめるため, 先頭から複数個の関 節が自由に運動できる状態にし，ワイヤケーブルを操作して先端を屈曲させた時の挙動を観測した . 図 8 は，第 10 リンクを台に固定し, 先頭から 9 個のリンクを浮かせた状態で, 直線姿勢から屈曲させた場合の挙動を示して いる.9 個のリンクがあれば円弧形状の確認には十分である. 先端の屈曲角を十分に低速に変化させた場合, 円弧 形状を保ちながら徐々に半径を変化させるように変形する．ワイヤ操作を速めると慣性の効果か現れて振動的な 挙動を示すが，この部分の制御については今後の検討課題である .

\section{5. 平面狭隘空間の探索}

\section{1 原理}

曲率微分に比例した屈曲力を発生する推進機構は, 左右の運動が拘束されている場合には推進力を発生し, 先 端か開放されている場合は円弧状の形状に安定化される．これは狭隘空間の探索問題に適した特徵と言える . 图 9 は蛇行した狭隘空間の途中に開放区間がある状況を示している . 体幹後方 (図中実線) は左側の狭隘部に拘束さ れ, 曲率の变化率に応じて推進力を発生する.直線や円弧形状の場合, 屈曲による推進力は生じないが, 後方か ら押すことで推進できる．サーボ剛性により形状を保持する作用があるため，駆動力の無い紐を押し込んだ場合 と異なり座屈は発生しない，先端分を含む開放区間 (図中破線部) においては操作者によって与えられた任意の 曲率の円弧上の形状に安定化する .一般的なファイバスコープのように , 先端のみが屈曲できる仕組みでは, 図 9 のような開放区間を通過して再び狭隘な経路に到達するのは困難である．これに対し，提案機構では開放区間に おいて円弧上に湾曲することで, 先端位置を操作することが可能で, ひとたび狭隘部の入り口を捉えて左右の運

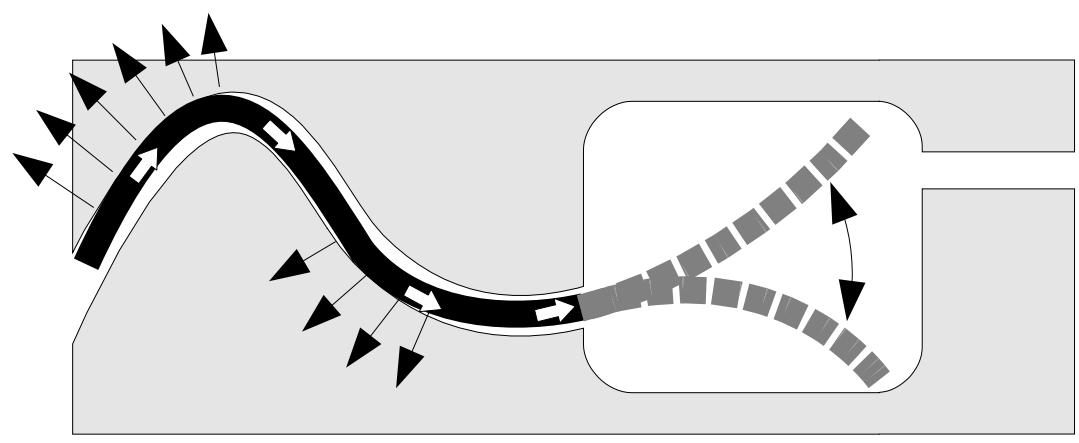

Fig. 9 Manipulator body in a constrained part (left) and open space (right) 
動が拘束されると，再び推進力を発生させることができる．

\section{$5 \cdot 2$ 実験環境亡 実験方法}

試作機による狭隘空間探索の検証のため，ポリアセタール製の板材に図 10 に示すような凹みを掘り込んだ実験 環境を作製した . 白色部が溝が掘り込まれた箇所であり，この部分を通過することができる．最も狭い部分は，体 幹の幅よりわずかだけ広く作られており，側方の動きは拘束される．また，体幹の底面とは滑りにより移動する が , ポリアセタール樹脂の自己潤滑性により摩擦力は低く抑えられている. 実験に際しては , 左側の間隙から侵 入させ，操作者が押し込みながら，分岐点や開放区間において必要に応じて先端部の屈曲角を操作する . 圧縮空 気の供給がない場合を先端のみが屈曲できる受動的なファイバスコープとみたて , 挙動の違いを比較する .

\section{$5 \cdot 3$ 実験結果}

実験を行った樣子を図 11 に示す . 図の左側の系列は, アクチュエータに加圧空気を供給していない場合で, 右 側は 0.4 MPa の圧縮空気を供給した場合を示している .いずれの場合も主たる推力は後方からの押力であり，圧 縮空気を供給した場合は推力が補助される . 非加圧時には, 最初の開放区間の開口部で進行方向か下方 60 度の方 向に制約され $(2,3)$, 次の狭隘部に到達できていない .一方，加圧時には操作者がワイヤケーブルを通じて開放区 間において先端部分を左方に屈曲させると, 先端部が大きく左方に湾曲し $\left(2^{\prime}\right)$, 狭隘部の入り口を捉えることに成 功している.2つ目の開放区間 $\left(3^{\prime}\right)$ においても同樣である.壁面によって拘束された時の形状が十分に大きな曲率 変化を持つ場合, 推進機構によって発生する推進力は摩擦力を上回り, わずかな押力で自立的に推進する $\left(4^{\prime}\right)$.

\section{6. ま と め}

本論文では, 蛇行推進の原理を機械的に実装した空圧駆動アクチュエータについて，側方運動が拘束されない 場合の挙動について考察し，開放区間を含む狭隘空間探索問題への応用方法と光の有効性を実験的に検証し，以 下の知見を得た .

・拘束された条件で最適な屈曲力制御則は, 開放区間においては円弧形状への安定化制御として作用する

・複雑な形状の空間において, 先端のみが屈曲できるファイバスコープに比して高い操作性を得た 高速に動作させた場合の動的な挙動, 接触部分の圧力分布等は, 今後の検討課題である .

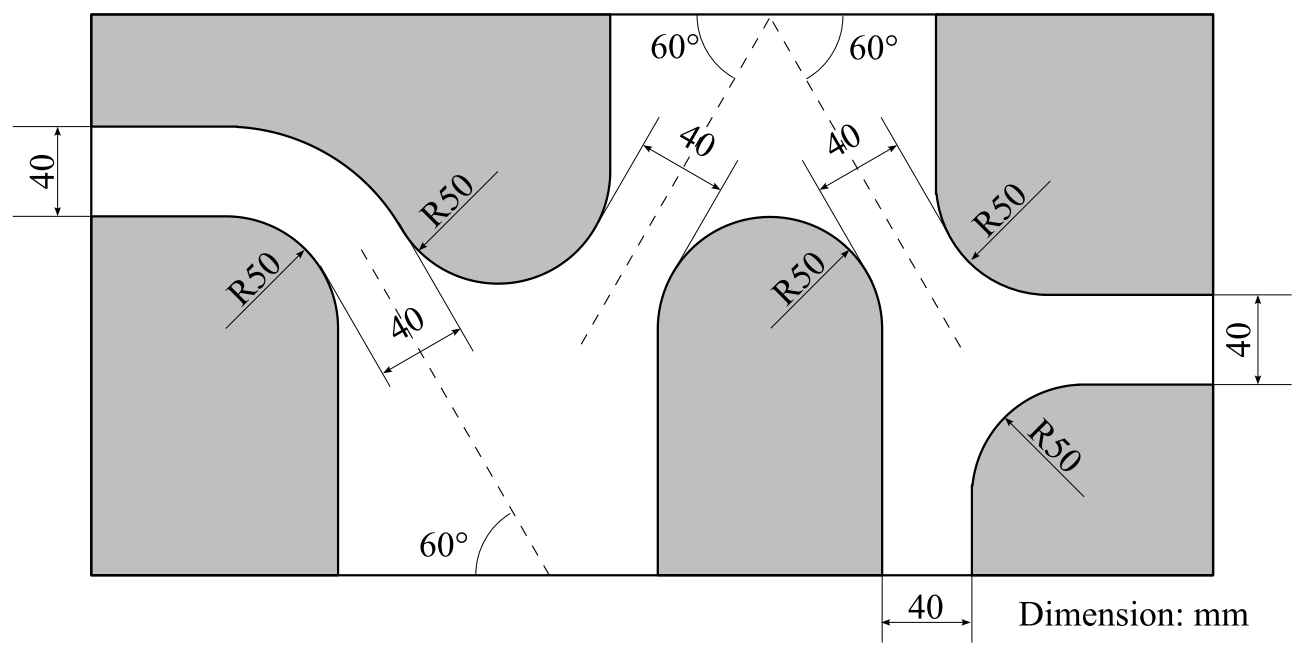

Fig. 10 Test bench for exploration in narrow space with cavities 

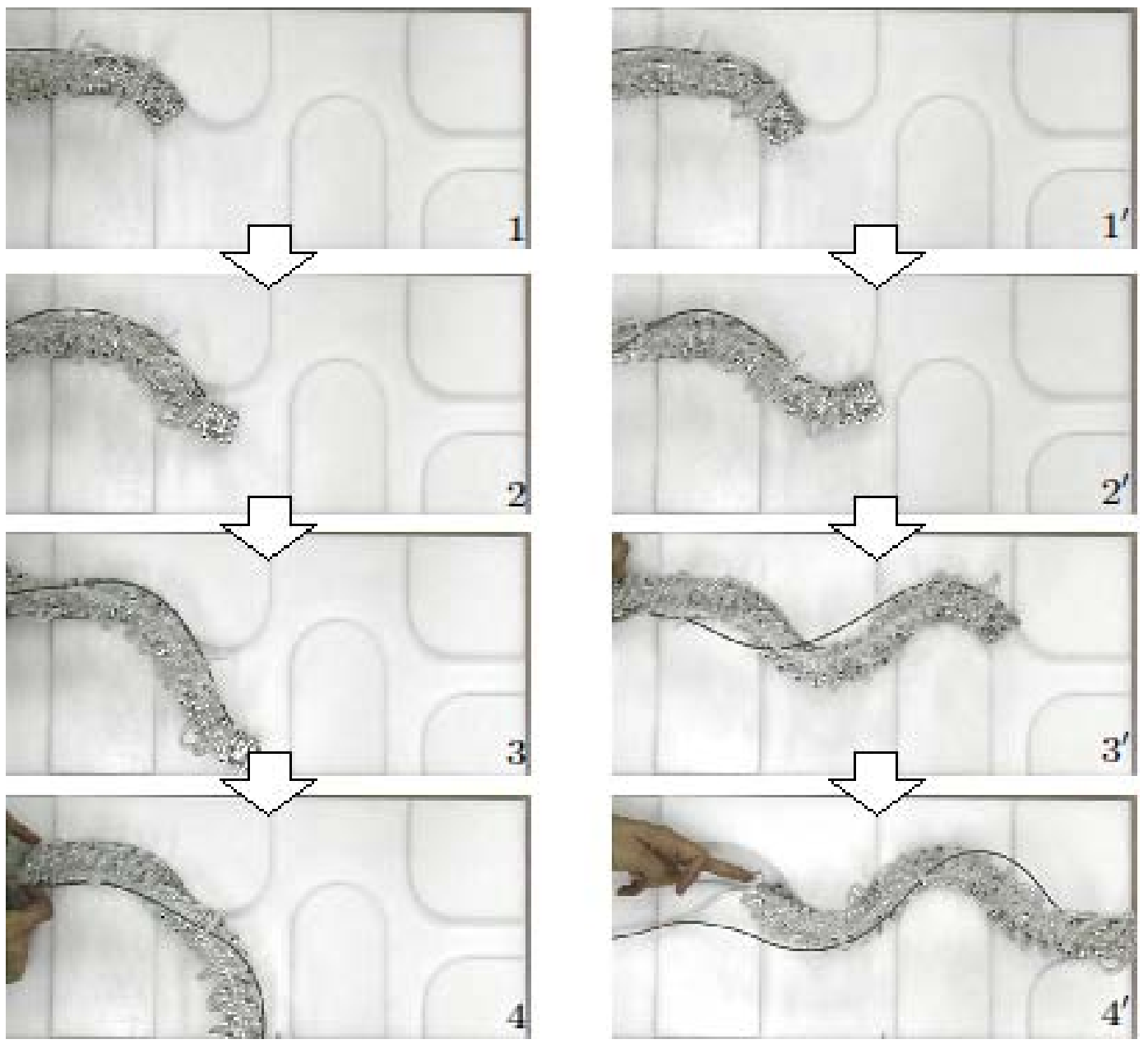

Fig. 11 Experiment of exploration: Without pressure supply (left); with pressure supply (right)

文献

（1）広瀬茂男,生体機械工学:やわらかいロボットの基本原理と応用, (1987), 工業調査会

(2) Chirikjian, G. S. and Burdick, J. W., "A modal approach to hyper-redundant manipulator kinematics", IEEE Transaction on Robotics and Automation, Vol. 10, No. 3 (1994), pp. 343-354.

(3) Chirikjian, G. S., "Hyper-redundant manipulator dynamics: a continuum approximation", Advanced Robotics, Vol. 9, No. 3 (1995), pp. 217-243.

(4) Date, H. and Takita, Y., "Control of 3D snake-like locomotive mechanism based on continuum modeling", Proc. ASME 2005 International Design Engineering Techinical Conferences (2005), No. DETC2005-85130.

(5) Moon, B. R. and Gans, C. "Kinematics, muscular activity and propulsion in Gopher snake", Journal of Experimental Biology, Vol. 201 (1998), pp. 2669-2684.

(6) 山田浩也, 広瀬茂男, “索状能動態の研究—一般化された ACM 移動力学の基礎式と Sinus-Lifting 滑走の解析—”, 日本ロボット学会論文誌, Vol. 26, No. 7 (2008), pp. 83-93.

(7) Date, H. and Takita, Y., "An electricity-free snake-like propulsion mechanism driven and controlled by fluids", Proc. IEEE/RSJ International Conference on Intelligent Robots and Systems (2009), pp. 3637-3642.

(8) Ohno, H. and Hirose, S., "Design of slim slime robot and its gait of locomotion", Proc. IEEE/RSJ International Conference on Intelligent Robots and Systems (2001), pp. 707-715. 